\title{
Editorial
}

\section{Mucosal Healing in Celiac Disease: A Necessary or Unrealistic Goal?}

\author{
Carlos Bernardes \\ Department of Gastroenterology, Centro Hospitalar e Universitário de Lisboa Central, Department of \\ Gastroenterology, NOVA Medical School, Faculty of Medical Sciences, Lisbon, Portugal
}

\section{Keywords}

Celiac disease - Mucosal healing · Histological remission .

Gluten-free diet · Endoscopic evaluation

\section{Cicatrização da Mucosa na Doença Celíaca: Objetivo Necessário ou Irrealista?}

\section{Palavras Chave}

Doença celíaca · Cicatrização da mucosa $\cdot$ Remissão histológica $\cdot$ Dieta isenta de glúten · Avaliação endoscópica

Over the last few decades, celiac disease has become one of the most extensively studied immune-mediated disorders worldwide. Erroneously considered as a rare condition in the past, its prevalence is now estimated to be about $1 \%$ in the majority of countries, including nonWestern ones [1]. Increasing awareness among physicians of the wide spectrum of clinical manifestations and laboratory abnormalities in otherwise healthy subjects has accounted for this phenomenon. Notwithstanding, beyond underdiagnosis, reports based on serological studies in different countries have suggested that the true

\section{KARGER}

karger@karger.com www.karger.com/pjg
(C) 2020 Sociedade Portuguesa de Gastrenterologia Published by S. Karger AG, Basel

Karger

Open access

This article is licensed under the Creative Commons AttributionNonCommercial-NoDerivatives 4.0 International License (CC BYNC-ND) (http://www.karger.com/Services/OpenAccessLicense). Usage and distribution for commercial purposes as well as any distribution of modified material requires written permission. incidence of this entity is growing when compared to the 1940s or 1970s [2-4]. Taking all this into account, it is reasonable to state that celiac disease will have a greater impact on our clinical practice in the near future.

In this issue of GE - Portuguese Journal of Gastroenterology, Silva et al. [5] report on the predictive factors and clinical impact of achieving histological recovery in celiac patients in clinical and serological remission. The authors verified that only about a third of the individuals had histological normalization upon endoscopic reassessment, which was performed within 12 and 24 months of glutenfree diet (GFD) initiation. Being a retrospective, observational study, their report could not be exempt of limitations, one of which is the selection bias due to the fact that endoscopic evaluation was not compulsory. Nonetheless, since patients' refusal to perform endoscopy is not uncommon in our clinical practice, this study presents an interesting analysis of the outcomes in regard to this particularly controversial topic in a real-life setting.

In contrast to its role for evaluation of nonresponsive celiac disease, the need for follow-up intestinal biopsies to confirm mucosal healing in asymptomatic patients with negative serology after GFD remains a matter of discussion between experts. Several reports suggested that persistent long-term villous atrophy could be associated with higher risk of forthcoming relapse, severe complications, including bone disease and lymphoma, and a trend 
to higher mortality [6-8]. However, some of those results have met criticism for their inadequate power, potential for referral bias, and lack of causality [9]; moreover, since they did not study the specific situation of patients who adhered and clinically responded to GFD, it is not possible to extrapolate the outcomes for those subjects. On the contrary, it is consensual that histological recovery is slow or may even not occur in a substantial proportion of adults during follow-up as long as 5 years; the reasons behind this occurrence are still unknown [8-11].

The most widespread explanation for the maintenance of histological damage despite strict and longstanding GFD is persistent but minimal gluten exposure. In those cases, gluten ingestion would not be significant enough to cause symptoms or to increase antibody titers but sufficient to produce some degree of intestinal inflammation and atrophy. In fact, some authors affirm that a total gluten eviction is not possible, thus hypothesizing that patients may continue to be chronically exposed to small quantities of gluten throughout life $[12,13]$. The correlation between the amount of gluten intake and the development of mucosal lesions is not clearly established, probably depending on a multiplicity of factors such as age, genetics, profiles of immune response, and microbiome [14].

Another plausible justification for the absence of mucosal healing could be related with long-lasting local immune response despite complete gluten elimination. Interestingly, histological normalization with GFD tends to occur more often in children than in adults [11]. Concurrently, several authors have described the possible development of gluten tolerance and disease latency following years of remission with GFD, namely in children or adults who were diagnosed during childhood [15-18]. In opposition to those, other patients might develop some degree of persistent mucosal immune response, regardless of gluten avoidance and consequent antibody normalization, maintaining long-term histological damage. Taking these data into account, one can hypothesize that such tendency to resolution versus persistence of intestinal immune response may be different among age groups.

Disregarding the underlying mechanisms associated with the failure to achieve histological normalization, the fundamental question is whether it translates to any relevant prognostic effect or change in the management of such patients. In accordance with previous data, Silva et al. [5] did not find any clinical impact in their cohort. They noticed that, in individuals with lower histological grades at diagnosis, complete histological improvement could be easier - or at least faster - to obtain; however, that could be in contrast to their findings regarding the relationship with lower levels of transferrin saturation at baseline, which, according to their suggestion, could mean that individuals with more severe - or prolonged - disease would recover more promptly.

Another important question to raise is whether complete histological normalization should be the target to pursue. Although some studies demonstrated that intraepithelial lymphocytosis appears to improve earlier than other lesions and to be a valuable marker for ongoing gluten intake, it is undeniable that their existence can also be linked to a variety of other conditions $[8,19]$. Furthermore, evidence showed that, if there is any prognostic impact attributable to persistent histological abnormalities, the presence of villous atrophy rather than intraepithelial lymphocytosis would be the determinant factor $[6,7]$. Silva et al. [5] only identified histological remission, defined as Marsh 0, in about one third of their patients; however, they found histological improvement, which is considered a reasonable goal for some experts, in about $80 \%$ of the cases, a result that is similar to previous publications.

In conclusion, this study reinforces that, in spite of all advances in the comprehension of the pathophysiology of celiac disease and its management, several doubts remain in relation to what is the most appropriate strategy for follow-up and surveillance. Future studies are required to specify the proper definition of histological remission, to establish the ideal timing for its evaluation and, above all, to determine if its accomplishment should be the ideal target or rather an unnecessary and unrealistic goal.

\section{Disclosure Statement}

The author has no conflicts of interest to declare.

References

1 Gujral N, Freeman HJ, Thomson AB. Celiac disease: prevalence, diagnosis, pathogenesis and treatment. World J Gastroenterol. 2012 Nov; 18(42):6036-59.

2 Lohi S, Mustalahti K, Kaukinen K, Laurila K, Collin $\mathrm{P}$, Rissanen $\mathrm{H}$, et al. Increasing prevalence of coeliac disease over time. Aliment Pharmacol Ther. 2007 Nov;26(9):1217-25.

3 Rubio-Tapia A, Kyle RA, Kaplan EL, Johnson DR, Page W, Erdtmann F, et al. Increased prevalence and mortality in undiagnosed celiac disease. Gastroenterology. 2009 Jul; 137(1):88-93.

4 Catassi C, Kryszak D, Bhatti B, Sturgeon C, Helzlsouer K, Clipp SL, et al. Natural history of celiac disease autoimmunity in a USA cohort followed since 1974. Ann Med. 2010 Oct; 42(7):530-8. 
5 Silva M, Peixoto A, Santos AL, Costa-Moreira P, Ferreira da Silva J, Dias E, et al. Predictive factors and clinical impact of deep remission in celiac disease. GE Port J Gastroenterol. 2020 Jan; 1-8. https://doi.org/10.1159/ 000505035.

6 Kaukinen K, Peräaho M, Lindfors K, Partanen J, Woolley N, Pikkarainen P, et al. Persistent small bowel mucosal villous atrophy without symptoms in coeliac disease. Aliment Pharmacol Ther. 2007 May;25(10):1237-45.

7 Elfström P, Granath F, Ekström Smedby K, Montgomery SM, Askling J, Ekbom A, et al. Risk of lymphoproliferative malignancy in relation to small intestinal histopathology among patients with celiac disease. J Natl Cancer Inst. 2011 Mar;103(5):436-44.

8 Rubio-Tapia A, Rahim MW, See JA, Lahr BD, $\mathrm{Wu}$ TT, Murray JA. Mucosal recovery and mortality in adults with celiac disease after treatment with a gluten-free diet. Am J Gastroenterol. 2010 Jun;105(6):1412-20.

9 Lebwohl B, Granath F, Ekbom A, Montgomery SM, Murray JA, Rubio-Tapia A, et al. Mucosal healing and mortality in coeliac disease. Aliment Pharmacol Ther. 2013 Feb;37(3): $332-9$.
10 Lanzini A, Lanzarotto F, Villanacci V, Mora A, Bertolazzi S, Turini D, et al. Complete recovery of intestinal mucosa occurs very rarely in adult coeliac patients despite adherence to gluten-free diet. Aliment Pharmacol Ther. 2009 Jun;29(12):1299-308

11 Wahab PJ, Meijer JW, Mulder CJ. Histologic follow-up of people with celiac disease on a gluten-free diet: slow and incomplete recovery. Am J Clin Pathol. 2002 Sep;118(3):45963.

12 Akobeng AK, Thomas AG. Systematic review: tolerable amount of gluten for people with coeliac disease. Aliment Pharmacol Ther. 2008 Jun;27(11):1044-52.

13 Collin P, Thorell L, Kaukinen K, Mäki M. The safe threshold for gluten contamination in gluten-free products. Can trace amounts be accepted in the treatment of coeliac disease? Aliment Pharmacol Ther. 2004 Jun;19(12): 1277-83.

14 Krishnareddy S. The Microbiome in Celiac Disease. Gastroenterol Clin North Am. 2019 Mar;48(1):115-26.
15 Hopman EG, von Blomberg ME, Batstra MR, Morreau H, Dekker FW, Koning F, et al. Gluten tolerance in adult patients with celiac disease 20 years after diagnosis? Eur J Gastroenterol Hepatol. 2008 May;20(5): 423-9.

16 Matysiak-Budnik T, Malamut G, de Serre NP, Grosdidier E, Seguier S, Brousse N, et al. Long-term follow-up of 61 coeliac patients diagnosed in childhood: evolution toward latency is possible on a normal diet. Gut. 2007 Oct;56(10):1379-86.

17 Schmitz J, Arnaud-Battandier F, Jos J, Rey J. Long term follow-up of childhood coeliac disease: is there a 'natural recovery'? Pediatr Res. 1984;18:1052.

18 Schmitz J. Is celiac disease a lifelong disorder? Clin Invest Med. 1996 Oct;19(5):352-6.

19 Montgomery AM, Goka AK, Kumar PJ, Farthing MJ, Clark ML. Low gluten diet in the treatment of adult coeliac disease: effect on jejunal morphology and serum anti-gluten antibodies. Gut. 1988 Nov;29(11): 1564-8. 